\title{
MINHA MISSÃO NO MUNDO
}

IRACEMA GA RÃ NASCIMENTO'

Kanhgág

HERBERT WALTER HERMANN ${ }^{2}$

UFRGS

CLÉMENTINE MARÉCHAL ${ }^{3}$

UFRGS

AUDISSEA KAPRI NASCIMENTO PADILHA ${ }^{4}$

UFRGS

\begin{abstract}
RESUMO: este texto se dirige para o "futuro", ou para uma "possibilidade de futuro", em que partimos do relato de vida da kujá Kanhgág Iracema Ga Rã Nascimento, adensada na trajetória etnográfica dos antropólogos Herbert Walter Hermann e Clémentine Maréchal. Inspirados por outros projetos, verdadeiros "manifestos cosmopolíticos", pretendemos situar tais relações e (des)encontros extrapolando nossas vidas. Não se trata aqui de uma conversa fortuita ou descontínua, mas de um diálogo e de trocas que ocorrem entre os autores desde 2012. Nos valemos de diversos espaços, e dos seres que neles habitam, para proliferar em vida e em boa história o material.
\end{abstract}

PALAVRAS-CHAVE: Relato Kanhgág; Iracema Ga Rã Nascimento; manifesto cosmopolítico.

ABSTRACT: this texts is driven towards a "future", or a "possibility of a future", in which we depart from the life story of Kanhgág kujá Iracema Ga Rã Nacimento, resumed in the ethnographic trajectory of Herbet Walter Hermann and Clémentine Maréchal, both anthropologists. Inspired by other projects, true "cosmopolitical manifests", we intend to demark such relations and (mis)matches by extrapolating our own life. It is not about establishing a fortuitous or discontinuous conversation, but a dialogue, a set of exchanges that have been

\footnotetext{
${ }^{1}$ Kujá, conselheira e liderança Kanhgág reconhecida na luta pelos direitos indígenas em Porto Alegre.

2 Doutorando em Antropologia Social na Universidade Federal do Rio Grande do Sul. Pesquisador associado ao Grupo de Antropologia da Economia e da Política (GAEP/UFRGS). E-mail: herbertwh@gmail.com.

${ }_{3}^{3}$ Doutoranda em Antropologia Social na Universidade Federal do Rio Grande do Sul. Pesquisadora associada ao Núcleo de Antropologia das Sociedades Indígenas e Tradicionais (NIT/UFRGS). E-mail: clementine.marechal@yahoo.com.

${ }^{4}$ Graduanda no curso de Administração Pública na Universidade Federal do Rio Grande do Sul. E-mail: knascimento.nascimentopadilha@gmail.com .

${ }^{5}$ Ver Kopenawa e Albert (2015). Sobre o conceito de cosmopolítica, consultar Stengers (2005 e 2007).
} 
occurring between the authors since 2012. We make use of multiple spaces, and of the beings that inhabit them, to proliferate, in life and in history, this material.

KEYWORDS: a Kanhgág account; Iracema Ga Rã Nascimento; cosmopolitical manifest.

\section{Introdução}

Iracema é uma liderança indígena ${ }^{6}$ reconhecida numa porção territorial considerável, que percorre a bacia do Rio Guaíba e do Rio Uruguai até o oeste do estado do Paraná, no sul do Brasil meridional. Desde sua chegada à cidade de Porto Alegre, no início dos anos 1990, procura visibilizar desacordos e desentendimentos ocasionados pelos órgãos do Estado brasileiro: aos usos da terra, ao governo dos corpos e à insistente tentativa de controle da população indígena - em síntese, do durável mal encontro histórico entre os Kanhgág e a "nossa civilização".

Essa apresentação não é única, mas singular em sua natureza. A lista de pesquisadores que estabeleceram contato com a kujá é longa, tanto em Antropologia Social, quanto em outras disciplinas acadêmicas. Os materiais publicados em forma de monografias, dissertações, teses, artigos, capítulos de livro e filmes, em alguma medida, e em certo grau, potencializaram a luta de Iracema e sua parentela naquilo que julga urgente: ensinar aos fóg, e também aos parentes, a respeitar $G a$, a mãe terra.

Suas palavras encontram-se em diálogos que presentificam duas décadas de contato com a ciência e a universidade. Podemos encontrar descrições e exemplos dessa relação temporalmente estendida em: Catafesto de Souza (1998), Freitas (2005), Rosa (2008), Aquino (2008), Saldanha (2009 e 2015), Jaenisch (2010), Eltz (2011), Gravato (2012),

\footnotetext{
6 "Indígena" é um derivativo do termo "índio", nomitativo bastante problemático, no sentido de expressar uma categoria genérica, colonial e ideológica imposta pelo colonizador para demarcar uma suposta condição de primitividade e inferioridade destas populações comparativamente a quem as designa dessa forma (URBAN, 1992). Catafesto de Souza (1998) preferiu usar os termos autóctones e/ou originários para demarcar a posição de anterioridade em relação aos colonizadores euro-referenciados; aqui, usamos "índio" e/ou "indígena" sem esquecer dessa arqueologia do contato.
} 
Schweig (2014), Maréchal (2015) e Hermann (2016), para citar apenas alguns. Não precisamos necessariamente recorrer a entrevistas de retorno com os pesquisadores para compreender a relevância que Iracema tem nesse contexto e em suas produções: lendo as notas de agradecimento em cada um desses estudos, verificamos essa vitalidade. Por exemplo, a antropóloga Ana Elisa de Castro Freitas (2005, p. 3), em sua tese, agradece "à família de João Carlos Padilha e Iracema Rã Ga Nascimento, por me introduzirem no universo Kanhgág em Porto Alegre e me darem a chave para a compreensão do Mrũr Jycre" - nada menos do que o conceito central de seu trabalho.

A proposta desse material é solidária aos demais textos do presente livro, um lampejo de esperança, um "contra", nas palavras de Clastres (2014), frente ao mundo que se agita na celebração da doutrina do (neo)liberalismo econômico e do racismo amplificado (seja institucional ou não). Assim, nos sentimos comprometidos a participar desse livro.

Cientes do desafio, acordamos que o material seria processado a partir de nossos corpos em sua completude experiencial e cósmica mãos, cordas vocais, tímpanos, globos oculares, pés, papilas gustativas, paisagens, sonhos, situações, etc. - , respeitando as formas próprias de conversação, linguagem e reflexão entre os autores. Entendemos que cada qual colaboraria com seus próprios meios de forma responsável e comprometida: os antropólogos, com suas notas, recortes e devolutivas; a kujá, com suas prescrições, falas e encaminhamentos vivenciais, e sua filha, com suas lembranças, percepções e desenhos. Todos assumindo uma responsabilidade, decidindo caminhar apontando a mesma direção: tornar esse relato um impulso guerreiro, seja para os parentes Kanhgág, seja para os fóg.

Iracema, desde o início, destacou que deveríamos escrever ponderando a partir de viagens, algumas que realizaríamos, visibilizando um fragmento de sua caminhada, nem por isso menor ou desimportante. Não se trata aqui de um falseamento autobiográfico de Iracema, pois a peculiaridade cultural do gênero literário não faz parte da formação da pessoa Kanhgág, tão pouco refletiria a intencionalidade dos demais autores. Iracema não aprendeu o domínio dos códigos e, especialmente, da escrita do branco, mas vê na possibilidade de aliança com alguns fóg uma multiplicação dos efeitos de seu discurso kujá. Como Saez (2006, 
p. 182) nos esclarece: "A autobiografia, longe de ser um discurso espontâneo de um indivíduo natural, é um gênero caracteristicamente ocidental [...]. Mas o Ocidente não é um só".

Assim, essa produção textual é apenas um dos diversos exemplos da operatividade prática da dualidade-complementaridade cosmológica Kanhgág, em que a diferença é entendida como complemento e fonte de potência (MARÉCHAL, 2015; HERMANN, 2016). Como exercício narrativo, estamos preocupados com a restituição de histórias silenciadas, subjetividades reprimidas, linguagens e conhecimentos subalternizados, marcas indeléveis da ideia de totalidade e da hegemonia nomeada da modernidade e da racionalidade (MIGNOLO, 2010), figura significativa da colonialidade do poder (QUIJANO, 2000).

Metodologicamente, optamos por não disfarçar o espaço-tempo, procedendo a localização situacional a partir da experiência vivida pelos autores em sua urgência social de mundo (ABU-LUGHOD, 2000), respeitando a esfera intersubjetiva do trabalho de campo e buscando não suprimir as realidades dialógicas, ou seja, afirmando sua coetaneidade (FABIAN, 1983). Pretendemos, com isso, propor uma crítica ao uso esquizogênico do tempo e do espaço, em que "grupos" são lidos como temporalmente ou espacialmente distanciados, o que reforça, mesmo involuntariamente, uma ordenação hierárquica entre os sujeitos envolvidos.

Tendo como mirada de trabalho a perspectiva acima mencionada, procedemos uma série de encontros na residência de Iracema, entre agosto de 2016 e fevereiro de 2017, para definirmos o material que deveria ser publicado. Havia a nosso dispor uma coleção de acontecimentos, em forma de diários de campo dos antropólogos, de seus próprios materiais publicados e de memórias, que permitiriam uma leitura para a escrita desse material. Contudo, Iracema chamou nossa atenção sobre a necessidade de viajarmos para a TI Nonoai com o intuito de reencontrar seu umbigo. Desencontro que perdurava vinte e cinco anos.

O evento paradigmático da viagem tornou-se, juntamente com os relatos anteriores concedidos por Iracema, o modo como ela teria se tornado uma kujá Kanhgág, a alavanca de propulsão e organização do texto. A maior parte dos diálogos aconteceram com a presença dos 
autores, mas também em reuniões em duplas ou trios, ou através de ligações telefônicas. Valemo-nos, também, do testemunho de Kapri, filha de Iracema, que sempre esteve imersa nos diversos processos de luta Kanhgág. Apostamos na força desses diálogos não apenas como negociações, mas como o próprio material a ser apresentado, como poderão ler na sequência.

O texto foi organizado em três partes: a primeira conta, desde a perspectiva de Ga Rã, como ela teria se tornado uma kujá Kanhgág. Animando situacionalmente os (des)encontros entre a cosmologia Kanhgág e a política ocidental, seu relato esclarece a presença de seres e de suas ações protagonistas, os efeitos e a potência dessas alianças, seja na recuperação do território, seja na cura de uma criança Kanhgág, e a ascensão da sabedoria derivada do conhecimento dos kofá, seus avós. O segundo momento apresenta os relatos sobre a viagem de reencontro de Iracema com seu umbigo. Como uma experiência intersubjetiva da kujá, da sua netinha e dos antropólogos, o texto ganha forma expondo o conteúdo de afetações (FAVRET-SAADA, 1990), situada numa territorialidade ancestral Kanhgág. Manifestamos, a partir desse encontro etnográfico, as tristezas e as alegrias da viagem, as transformações da paisagem e o empoderamento de Ga Rã e de sua neta, Vẽnh fej, a partir do banho no goj pixé em Nonoai. A última parte corresponde ao relato de Kapri, filha de Iracema, que lembra os trabalhos da sua mãe desde que ela era criança e de como a kujá levou adiante esses conhecimentos no parto de sua neta, Sofia, filha de Kapri. Esses relatos são resultado de conversas e de uma convivência cada vez mais forte com os antropólogos. 


\title{
Como me tornei uma kuja
}

\author{
Procuramos a força através do fogo, \\ a água é a clareza, \\ a árvore é a vida \\ e a terra é a mãe
}

Eu nasci em Nonoai, sou uma Kanhgág, foram meus avós que me criaram, que são as pessoas sábias que me deram banho para continuar com a crença, aquilo que os brancos chamam de religião. Meus avôs sempre acreditaram mais na natureza, onde está o nosso trabalho. É pra ser assim, sempre nós tomamos banho, o chá, e para acompanhar tudo isso tem que ter uma pessoa de idade, como meus avós, que são preciosos para nós Kanhgág.

As pessoas hoje conhecem Nonoai só como uma cidade, mas elas não sabem que o nome da cidade vem do meu antigo avó, Nonohê. Meus avós me contaram que um dia um colono, um fóg, chegou na nossa terra, no centro da nossa aldeia, que naquela época ocupava onde hoje é a praça principal da cidade de Nonoai. Esse colono alemão chegou quase morrendo de tuberculose, seus filhos traziam ele numa cama trançada, puxada por um cavalo. Eles se perderam perto do rio goj vén, onde meu vô estava pescando. Ele viu os colonos e ajudou a curar o fóg. Meu avô passou vários tipos de remédio nele, mas foi a banha de foîr (porco espinho) que o salvou.

Daí, como meu avô salvou o colono, na região eles colocaram o nome da cidade em sua homenagem. Mas, os fóg não sabem falar direito o Kanhgág: em vez de eles dizerem Nonohê, eles ainda falam Nonoai.

\footnotetext{
${ }^{7}$ Os kujá são os médicos Kanhgág que pegam os remédios da floresta. Eles sabem cuidar muito bem dos corpos, eles podem saber fazer os partos, curar as pessoas doentes com remédios do mato e também eles sabem sonhar. Eles podem se comunicar com os mortos e com outros kujá nos seus sonhos. Esses sonhos são muito importantes para nós Kanhgág, porque é como um meio de comunicação. Podemos ficar sabendo de eventos antes que eles aconteçam. Os fóg costumam chamar os kujá de xamã ou pajé, mas eu prefiro dizer kujá porque é o nome especifico dos Kanhgág.

${ }^{8}$ As autoras e o autor deste texto depositam confiança nos aprendizados repassados à Iracema por seus kisifi (mestres) e por ela retransmitidos em longas sessões de diálogo e encontros, alguns aqui visibilizados. Tais momentos serão elaborados em forma escrita e através de imagens escolhidas com o intuito de sensibilizar diversas audiências. Gostaríamos de incendiar certezas, clarificar pensamentos e vivificar trocas em torno de $G a$, de onde falamos e ouvimos, a partir do entrelaçamento de Iracema conosco. Entendemos que esse texto seja parte de um projeto cosmopolítico em torno da terra e da vida Kanhgág.
} 
Nascimento, Hermann, Maréchal e Padilha - Minha missão no mundo.

Imagem 1: Iracema e dois de seus filhos, Katumé e Kenxé, na estátua de Nonohê na entrada da cidade de Nonoai.

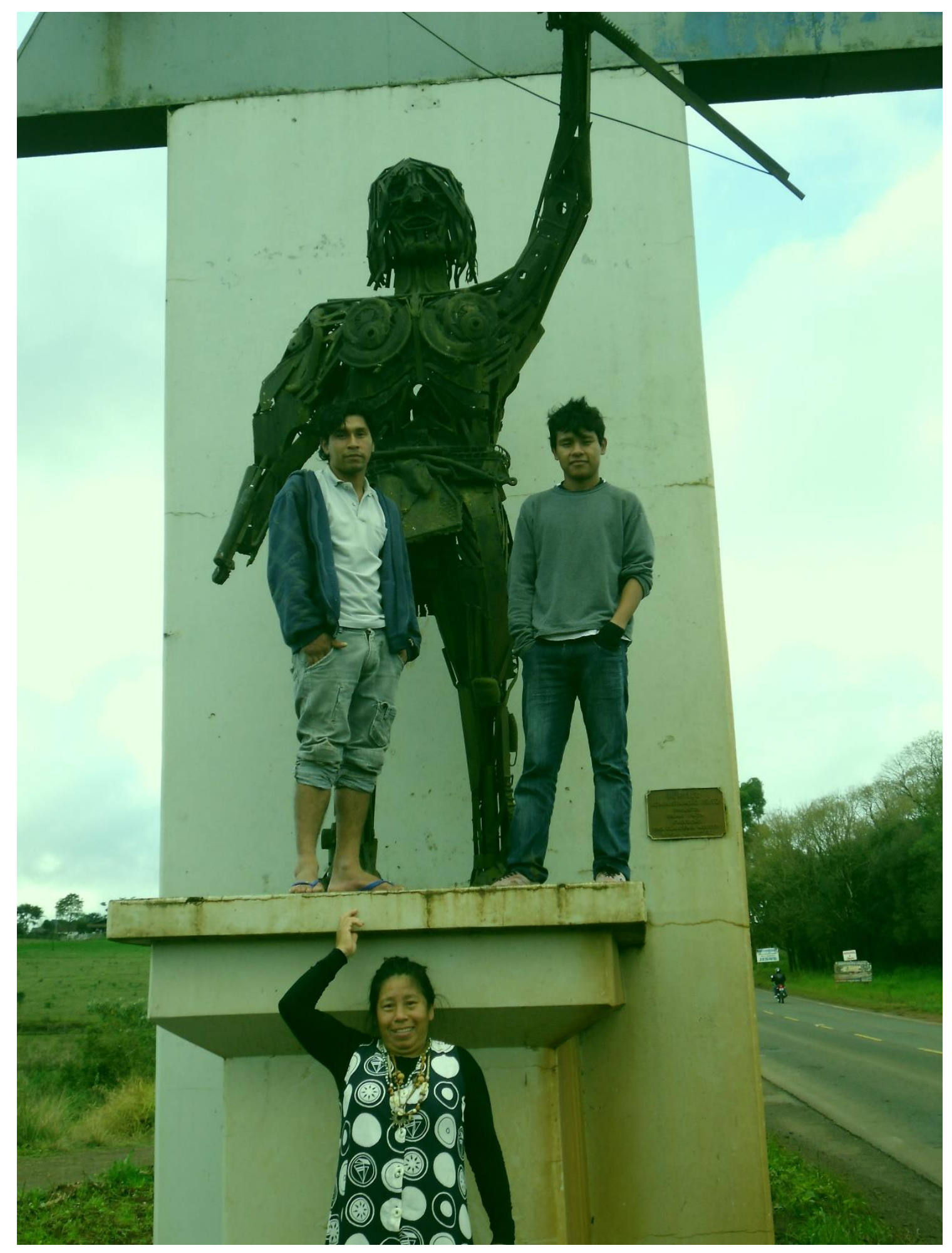

Fonte: Fotografia de Clémentine Marechal, 2014. 
Nascimento, Hermann, Maréchal e Padilha - Minha missão no mundo.

Imagem 2: Iracema abraçando o ipê da praça de Nonoai, antigo lugar de reunião dos seus antepassados.

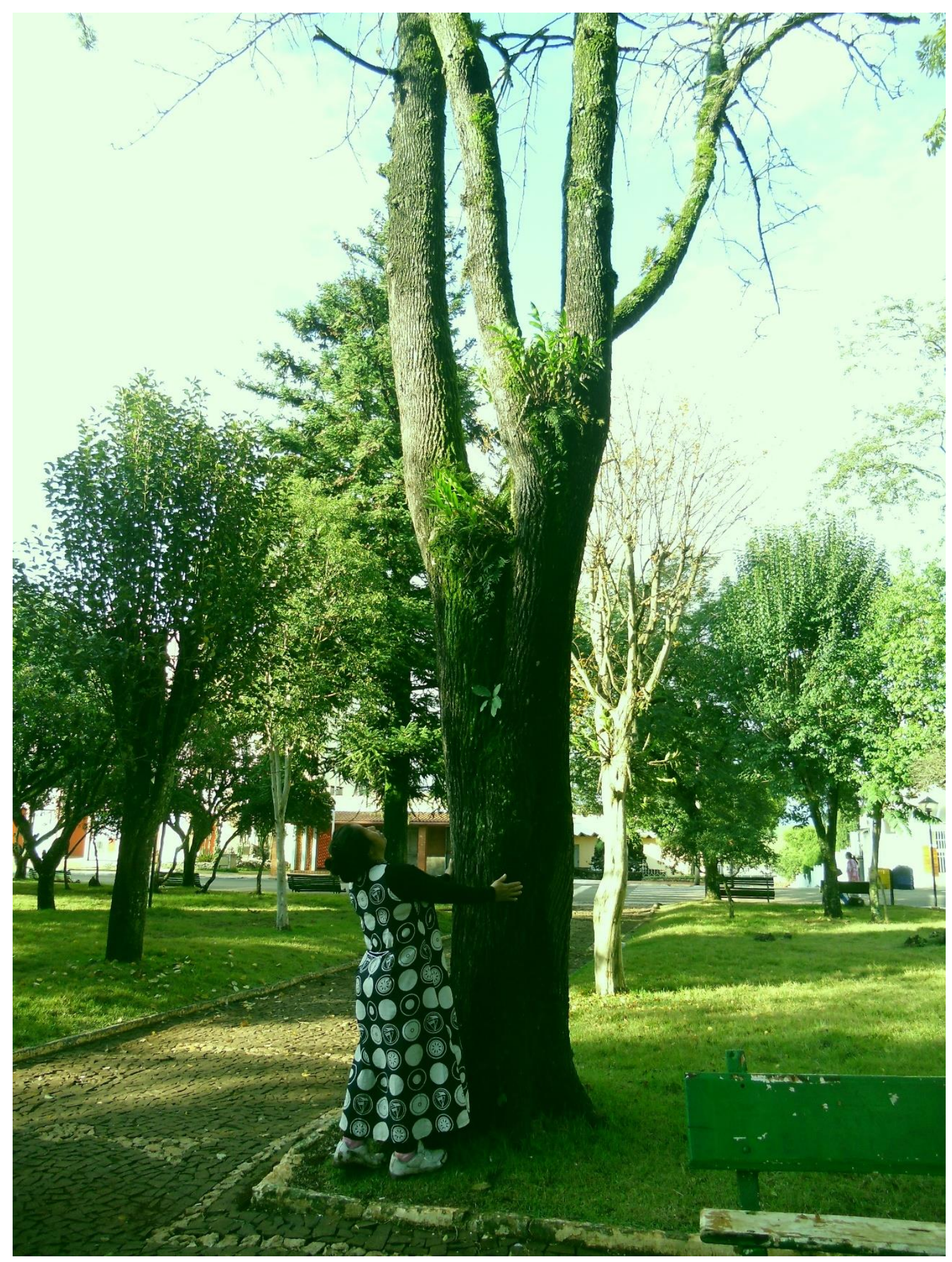

Fonte: Fotografia de Clémentine Marechal, 2014. 
Meu primeiro nome Kanhgág foi Ga Téj (redemoinho). Esse nome é um nome kanheru que meu pai Penĩ (tartaruga) me transmitiu. O que significa Ga Tés? Significa terra que faz o moinho voar, terra que voa.

Quando tinha quatro anos de idade, meu avô e minha avó me levaram no meio do mato, onde tive que ficar durante três noites. Meus avôs chamaram seus jãgré 9 . O mĩg (tigre do mato), o jãgré da minha avó, chegou acompanhado de dois casais, eram os seus filhos. O jãgré do meu avô também chegou, ele é o jakũnh (leão baio), o cacique dos tigres do mato. Meu avô me deixou sentada longe dele para ver qual dos tigres iria me escolher e também para me testar, para ver se não me assustaria. Quem me escolheu foi o mĩg sĩ (tigre pequeno). Eu estava bem tranquila, peguei eles no colo e dei carinho.

Logo depois chegou o jakũnh (jãgré do vô) para me mostrar que me aceitava na família, ele lambeu meus pés e minhas mãos. Já sabia que podia confiar e contar no meu jãgré, o mĩg sĩ. Soube que, se precisasse de mais apoio, poderia chamar o jakũnh, mesmo ele sendo da outra marca, dos kamé, ele me ajudaria. Quando estava com cinco anos, meu avô me deu um novo nome, para me pôr no caminho, para aprender e me tornar uma kujá. Para isso, eles fizeram um vẽnh-kagta kypég, que para que os fóg entendam seria um "batismo", mas com remédios do mato. Aí, meu avô me deu o nome de Ga Rã, que seria Terra e Sol em português. Como esse nome é de kujá, ele tem as duas marcas, a kanheru e a kamé. Rã é sol, pertencente a marca longa kamé. Ga é terra, pertencente a marca redonda kanheru10.

\footnotetext{
${ }^{9}$ Os jãgré são os guias dos kujá. Sem eles, o kujá não sabe como usar os remédios, nem quais são os que deve usar. Eles são muito importantes para nós, a maioria são animais, como o tigre, o leão baio, alguns pássaros, tais como: a coruja, o papagaio, a águia entre outros.

${ }^{10}$ Para você entender nossas marcas, tem que pensar que as pessoas Kanhgág nascem com uma marca redonda que se chama rã rór, que é da metade kanheru, ou com uma marca longa, rã tej, que é a dos kamé. Todos os Kanhgág têm marca, os animais e as plantas também têm. Nós chamamos as pessoas que têm a mesma marca de regré, que em fóg seria como "irmão", e as pessoas que não são da mesma marca de jamré; os fóg traduzem como "cunhado", mas é muito mais do que isso. Entre jamré é proibido brigar, eles estão para nos dar conselhos, eles são nosso complemento, porque eles têm coisas que nós não temos. Para casar, sempre temos que buscar uma pessoa da outra metade, não podemos casar entre regré: para vocês entenderem, seria como se os fóg casasse entre irmãos. Hoje tem problemas aqui em Porto Alegre, porque temos muitas pessoas kamé, daí as pessoas casam entre si e só se reproduz uma marca, isso traz problema para nossa sociedade. Meu filho, Katumé, ele diz que prefere casar com uma fóg do que com uma moça da mesma marca, porque se você casar com fóg, tu enfraquece tua raiz, sim, mas pelo menos não fica doente, se casa com regré tu podes ficar muito doente.
} 
Naquele mesmo dia, meu avô deu minha "missão" no mundo. Ele pegou na sua mão dois bichinhos, um ópẽ (gafanhoto) e um tupé matén (louva-deus) ${ }^{11}$, me mostrou como eles caminhavam sem avançar um por acima do outro. Eles podiam comer a mesma comida sem se machucar. Ele me perguntou se eu tinha entendido o que ele queria dizer, se eu tinha entendido minha "missão". Eu olhando os dois bichinhos pensei que queria me mostrar o respeito entre nossas duas marcas, respeitar o outro lado, para que o kamé sempre respeitasse o kanheru e o kanheru sempre respeitasse o kamé. Ele deu risada, me disse que sim, era para respeitar o outro lado, mas além da nossa cultura Kanhgág. Ele me disse que eu iria conhecer outras culturas e também outros mundos, não somente o mundo dos fóg. Minha missão então era: fazer conhecer para os outros a nossa cultura Kanhgág.

Para isso, para aprender a cultura dos fóg, fui para escola deles, mas eu não gostava, porque todas as aulas eram em português. Me indignava, porque eu queria estudar na minha língua. A professora não gostava quando falava em Kanhgág e ela começou a me castigar. Ela me obrigava a ficar de joelhos na frente de todos os alunos, ajoelhada sobre os grãos de milhos, ficava durante muito tempo.

Quando meu avô viu os ferimentos do castigo nos meus joelhos, ele ficou bravo e me disse que no dia seguinte iria me acompanhar até a escola. Primeiro, ele curou minhas feridas, me acordou bem cedinho e me levou para tomar um banho de rio, pegou as ervas na beira d'água e fez uma mistura, colocando nos meus joelhos machucados, atando as folhas com uma fibra de um ramo de urtigueira (Urtica circularis). Bem cedinho, no outro dia, chegamos na escola, meu avô pegou todos os cadernos e falou para minha professora que já não iria mais para a escola. Ele me disse: "Fi tÿ ymã mág to un-on kajrẽn nĩ nĩ, ã mÿ ke pi"12.

Desde então, não fui mais à escola dos fóg e aprendi com meus parentes a sonhar e a curar. Acho que meus avôs já sabiam que eu seguiria seus passos, éramos sete meninas, mas foi para mim que ensinaram os conhecimentos.

\footnotetext{
${ }^{11} \mathrm{O}$ tupé matén é um animalzinho que nunca ninguém pode matar porque ele canta sem parar, por todo tempo, às 24 horas, como falam os fóg.

12 "Ela está ensinando todas as mentiras sobre o Brasil, esse caminho não é para ti" (Tradução de Iracema).
} 
Eu fui escolhida já dentro da barriga da minha mãe. Fizeram um teste, lançaram as cobras e elas não chegaram em mim, mas quando nasci foi minha mãe que levou o susto. Com o susto, o leite secou no seu peito e tiveram que chamar o Zé Gordo, jamré do meu pai. Minha mãe teve que tomar muita água de mel para se curar. O Zé Gordo levou com ele as cobras e, quando eu tinha quatro aninhos, minha mãe me levou na casa do Zé Gordo. Eu estava do lado de outras crianças e ele soltou as cobras, todas as meninas correram, ficamos só eu e mais um menino e as cobras não nos morderam. O menino até hoje vive, ele é kujá também e mora no Paraná.

Eu gostava de passar tempo embaixo das árvores e pensar, prestava muita atenção nos meus parentes. Desde pequena aprendi a sonhar. Aprendi com a ajuda dos meus avôs e de outros kujá que foram meus mestres, meus kisifi, e dos meus parceiros, que são meus jãgré. Um dos primeiros sonhos que tive foi quando eu e minha família fomos para o Paraná para ajudar o Ângelo Kretã a retomar a terra Kanhgág de Mangueirinha. Essa terra estava invadida pelos colonos, e o Kretã nos chamou para ajudá-lo. Junto com 75 famílias, saímos de Nonoai para apoiá-lo. Eu tinha uns dezesseis anos a primeira vez que sonhei com a retomada dessa terra.

O pai estava a ponto de ir junto, com Ângelo Kretã, atrás dos colonos para expulsá-los daquelas terras. À noite bebi um chá de ervas e sonhei com meu pai. Ele estava carregando cestos e andava na frente de um monte de pessoas, estava indo para as casas dos colonos junto com Kretã para expulsá-los. Mas, no meio do sonho, eu caí da cama! Acordei puxando a mão da minha irmã, isso porque no sonho queria puxar a mão do meu pai. Eu sabia que ainda não era a hora certa. Um tempo depois, numa quinta-feira, meu pai me perguntou de novo: "Que temos que fazer agora para retomar as terras?".

Eu disse para ele que tínhamos que fazer um gá kri pĩ (fogo no chão). Eu tomei outro vẽnh-kagta, um chá de ervas do mato. Eu trouxe folhas verdes para colocar no fogo e fazer fumaça e, no meio dessa fumaça, eu vi meu pai no meio de muitos parentes apoiando Kretã e, acima da fumaça, uma krĩg (estrela) brilhando. Essa estrela, quando tu sonhas, significa que teu sonho vai ter retorno. Então eu sabia que já era a hora de expulsar os colonos da nossa terra. Eu comentei para meu pai 
o que tinha sonhado. Dito e feito: uns dias depois estávamos acampando no que era uma fazenda, e até agora, nessa terra, moram meus parentes.

Aprendi com os kisifi a curar as pessoas, isso é algo que até agora eu faço. Atualmente, com os remédios que o mato nos dá, eu ajudo na cura de muitos fóg, porque alguns deles acreditam nos saberes dos Kanhgág. As ervas agora são difíceis de encontrar, porque muitos fóg destruíram e seguem destruindo tudo e, pior ainda, hoje alguns de nossos próprios parentes estão do lado dos fóg, foram contaminados pelo dinheiro. No tempo do SPI'3, os fóg trocaram nossas árvores por plantações de soja, e isso só trouxe dinheiro para eles e morte para nós. É triste, porque nossa cultura não é a cultura do dinheiro, a gente tinha tudo e agora temos que nos vender. Pois é, hoje alguns poucos aprenderam demais a cultura dos fóg e estão explorando seus próprios parentes.

Eu não aprendi sozinha a curar. Os meus parentes e parceiros me apoiaram. Sem os jãgré, não consigo curar, porque eles sempre me mostram os remédios que devo usar.

Uma vez curamos um menino que morava em Laranjeiras (um dos "setores" da TI de Nonoai). Ele tinha ficado mudo, não conseguia mais falar. Ele havia levado um susto depois de ver uma cobra na margem do rio. Como a cobra viu que ele se apavorou, ela levou o kuprĩg ${ }^{14}$ dele junto com ela. A família dele me pediu ajuda. Eu tomei um chá de ervas e consegui sonhar com ele. Mas, esse trabalho foi um trabalho muito longo, demoramos mais ou menos um ano inteiro para curar a criança. Eu sonhei com ele durante três luas, kysã tãgtũ. Mas, não foi sozinha que eu curei ele, eu curei ele junto com meus parceiros kujá, porque o menino teve que se fortalecer.

Nos meus sonhos me comuniquei com meus kisifi, Jorge Garcia e Marcolina, e também com outro kujá que eu nunca tinha visto antes, era

\footnotetext{
${ }^{13}$ Serviço de Proteção dos Índios. Criado em 1910, era o órgão encarregado de "civilizar" os índios e "integrá-los" na sociedade nacional, implementando escolas nas reservas indígenas e obrigando aos indígenas a trabalhar em lavouras. Foi extinto e substituído em 1967 pela Fundação Nacional do Índio (FUNAI).

${ }^{14}$ O kuprĩg é a "alma" da pessoa, seu "espírito". Quando levamos um susto, é nosso kuprĩg que fica preso. Os espíritos ruins dos mortos, os venh kuprig korég, aparecem e podem capturar os kupríg mais fracos. Quando teu kuprĩg fica preso, pode ficar doente, então precisa da ajuda de um kujá para afastar os venh kuprig korég e recuperar teu kuprĩg. Geralmente, os venh kuprĩg korég tomam a forma das cobras, por isso que quando sonha com cobra tem que matar, se tu não matar ela então tem o risco de ficar muito doente, porque ela pode capturar teu kuprĩg.
} 
um homem de cabelo bem branco do estado de Santa Catarina. Com a ajuda dos nossos jãgré, cada um de nós pegou um vẽnh-kagta para dar para a mãe da criança doente. Com esse remédio ela fez um chá. A mãe da criança estava presente nos sonhos também. Ela precisava chamar seu filho ao mesmo tempo em que dava para ele os vẽnh-kagta, três vezes, convidando-o para ir para casa. Esse vẽnh-kagta ajudou a acalmar ele e a fortalecer a sua respiração, porque a respiração ficou presa durante o susto que levou ao ver a cobra.

Ele teve que beber o remédio até o som da sua voz sair. No meu sonho, no último sonho, que foi quando ele voltou a ter a voz, ele estava ainda na beira do rio, preso lá. Eu fui lá e o ajudei a não ter mais medo da cobra, sentando ao seu lado. A cobra apareceu de novo e o ajudei a pegar ela e lançá-la no rio. Quando ele conseguiu lançar a cobra, seu kuprĩg estava livre. Há um par de anos, eu vi ele em Porto Alegre, estava bem e falava.

Moramos muito tempo em Mangueirinha, no Paraná, na terra retomada, onde apoiamos o Ângelo Kretã. Acho que foi mais de dez anos lá, mas, assim como meu pai sentia falta do seu umbigo, que estava em Serrinha, eu sentia falta do meu umbigo, que estava em Nonoai. Só que lá, em Nonoai, os fóg da Funai15, de mãos dadas com os fazendeiros, incentivavam os nossos parentes a arrendar nossa terra. Os fazendeiros ofereciam muito dinheiro para apenas alguns parentes plantar na nossa terra, e os agentes da Funai, que eram "responsáveis" por nós, ganhavam dinheiro por esse plantio ${ }^{16}$.

Meu pai lutava sempre para proteger nossas árvores, nossa mata, então ele se levantou contra o cacique, junto com outros parentes, que também eram contra essa política de fazer aliança com nossos inimigos. O cacique não gostou da rebeldia e mandou todos embora, por isso que muitos Kanhgág estão aqui em Porto Alegre hoje. Porque suas famílias, seus pais e seus avós, se rebelaram contra os arrendamentos de terra que até hoje seguem nas nossas terras.

Chegamos em Porto Alegre, para morar, no final dos anos 1980; aqui começamos a fazer nosso material para viver, nosso trançado em

\footnotetext{
${ }^{15}$ Fundação Nacional do Índio.

${ }^{16}$ Sobre a dinâmica da FUNAI em incentivar o arrendamento de terras das comunidades indígenas no Brasil, ver Pozzobom (1999).
} 
cipó e taquara. No início, a sociedade não queria a gente aqui, diziam para que nós voltássemos para o mato, chamavam de bugre, ofendiam, mas aos poucos fomos amansando eles. Nosso artesanato foi quem nos sustentou, viver pagando conta nunca foi fácil. Fizemos amigos fóg que nos apoiaram, que aprenderam com a gente; fui professora de muitos estudantes, que hoje são professores na universidade. Agora, eu até sou professora na universidade dos fóg, faço atividades parecidas, como passar conhecimento e sabedoria, mas recebo em troca uma "bolsa", não um "salário", isso ainda é estranho para mim. Acordo cedo, pego ônibus, falamos com os jovens e até ensinamos os sabidos da cultura, nós trabalhamos muito. Ajudamos a fazer filmes e a escrever livros mostrando nossa cultura, muitas vezes para lutar, para nos defender, defender Ga, que não tem dono.

De viagens, encontros e lutas: notas a partir da visita ao umbigo de Iracema

Iracema, quando apresentada à ideia de escrever um artigo sobre sua "caminhada", acolheu imediatamente a proposta, mas ponderou uma série de ressalvas. Programamos uma viagem em direção a Nonoai em novembro de 2016, com o intuito de Iracema reencontrar seu umbigo, após vinte e cinco anos. Tratávamos essa viagem como um dos desafios em escrever "em termos compartilhados" a "biografia" de Iracema. Uma vida que reúne muitas outras, incluindo as nossas próprias. Sairíamos nós três e mais a netinha de Iracema, Vẽnh Fej, em direção ao noroeste daquilo que hoje chamam de estado do Rio Grande do Sul. Aquela viagem iria permitir a Iracema fortalecer a vida dos seus antepassados, reatualizando sua memória na nossa. Assim, as palavras, os ensinamentos, a experiência dos seus avós continuarão sendo um impulso para o futuro dos jovens Kanhgág.

Durante a viagem trocaríamos saberes sobre nossas próprias "caminhadas", assuntos de interesse das partes. Afinal, como chegamos até ali? Quais foram nossas lutas? O que nos reunia e nos afastava? Quem eram nossos parentes? O que havíamos aprendido com eles? Contando sobre nossas vidas, aprendíamos um pouco mais sobre as tramas que 
sucederam, as experiências que marcaram e os pontos de encontro que realizávamos. Iracema, após uma longa meditação, nos narra sobre seu tempo com uma irmã de seu pai, uma Kanhgág "bem branquinha", que fugiu de Nonoai para morar na cidade de Pelotas. Assim como a tia, Iracema fugia de um casamento arranjado a contragosto. Com o apoio de seu pai, Iracema realizaria a primeira grande viagem fora da TI Nonoai. $\mathrm{O}$ plano era encontrar a irmã de seu pai em Pelotas e permanecer por lá, até que fosse oportuno voltar a Nonoai, livre das obrigações do casamento.

A irmã de seu pai se identificava como uma Chinesa para a comunidade pelotense. Residindo numa das "vilas" da cidade, ou seja, na periferia, entendia que a estratégia lhe pouparia de constrangimentos com a população local. Iracema viveu com ela aproximadamente dois anos e ainda lembra de suas idas ao centro da cidade de Pelotas, guiada e acompanhada por um "primo emprestado", um jovem negro adotado ainda criança por sua tia. Suas primeiras andanças na urbe seguiam os conselhos dessa tia e seu adotado: Iracema ouvia com atenção e procurava seguir rigorosamente as indicações. Conviveu com outros fóg, além daqueles com que já convivia na TI de Nonoai. Acompanhada da tia, fora visitar uma comunidade de pescadores que acredita ser na cidade de Rio Grande, num dos locais em que seu pai Penĩ possivelmente passava temporadas de pesca. Iracema recorda que, quando ela era criança, seu pai saía em jornadas de pesca e caça por longos períodos; brincando, diz ter procurado irmãos desconhecidos entre aqueles pescadores, pois seu pai era bastante alegre e gostava de se divertir.

Saindo da cidade de Porto Alegre em direção a Nonoai, percorreríamos um longo trecho da rodovia federal BR-386 Leonel de Moura Brizola 17, um dos políticos que, em 1962, fora responsável pela redução territorial do aldeamento de Nonoai, um dos nomes conhecidos por Iracema a partir das histórias contadas pelos parentes.

\footnotetext{
${ }^{17}$ A renomeação da rodovia ocorreu em 19 de dezembro de 2007, através da Lei federal n. 11.620. A pesquisadora Lígia Simonian traça de forma precisa a política anti-indígena no Rio Grande do Sul, encabeçada por Leonel de Moura Brizola enquanto era governador do estado no final de 1950 e início dos anos 1960. Afinal, ele exerceria um "papel de destaque quanto à expropriação dos toldos indígenas" (SIMONIAN, 2009, p. 479).
} 
Imagem 3: Foto do acervo da família de Iracema, apresentada por ela ao Herbert enquanto ele escrevia sua dissertação. Os policiais eram presenças constantes nas aldeias do RS, um dos objetivos era fazer valer a política de isolamento, TI Nonoai.

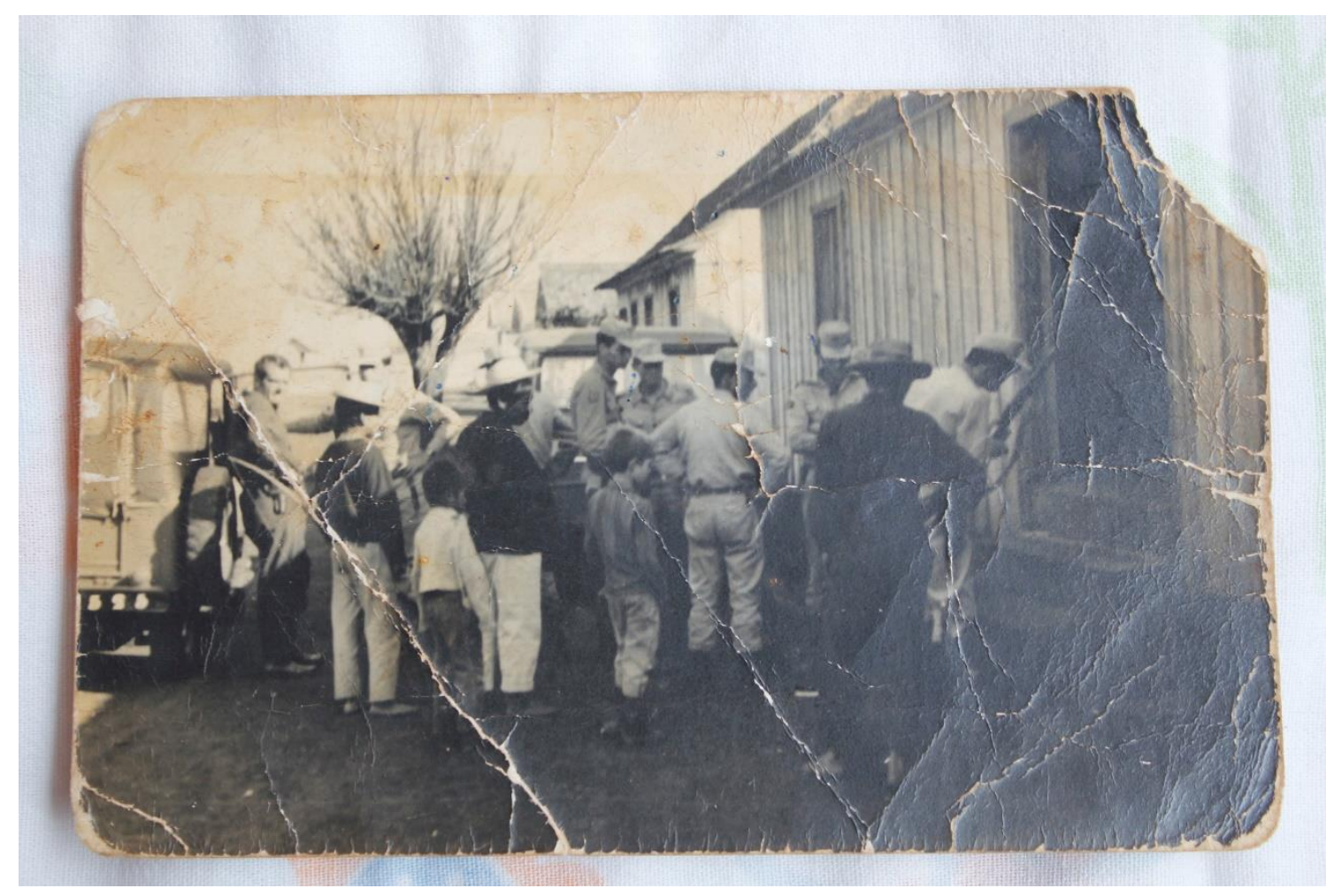

Fonte: Autor desconhecido, 197?

Observando a região que percorríamos, víamos uma imensidão, formada por campos de soja sinalizados por placas de empresas multinacionais e empreendimentos locais em associação, executoras de biopolíticas em torno de sementes geneticamente modificadas. Não há como esquecer da lição detalhada por Michel Foucault (2002 e 2008) sobre o biopoder e a biopolítica quando vemos tais paisagens, no limiar do nosso "século biológico" (RABINOW e ROSE, 2006, p. 27) em torno das "sociedades de controle" (DELEUZE, 1995). As sementes transgênicas da Monsanto, Pioneer Dupont, Syngenta, Basf, Bayer, Dow e suas associadas locais, Cotrisoja e Cotrisal, concatenavam naquelas placas preocupações de Iracema em torno de sua terra e, simultaneamente, concretizavam evidências sobre as racionalidades contemporâneas e as tecnologias de biopolítica. 
Sentíamos o cheiro do veneno, do agrotóxico, que "protegia" as lavouras de milho e soja. Distante, esperávamos passar por algum capão, quando nos dávamos conta do odor do Eucalipto (eucalyptus citriodora): percebíamos quantos clones poderiam formar uma "área verde", uma "floresta renovável", e aquilo nos inebriava. Eram poucos, mas ainda restavam alguns capões de fág, pinheiros de araucária (araucaria angustifólia). Iracema mudava o semblante quando os via; Vẽnh Fej, nascida em Porto Alegre, não entendia muito bem por que sua avó se entristecia ao ver aquela paisagem tomada pelo agronegócio.

Algumas horas após o início da jornada, parávamos num dos acampamentos indígenas da rodovia, no trecho da cidade de Carazinho, onde Clémentine etnografou, entre 2013 e 2015, as relações coloniais ainda vigentes na região, exercidas contra os coletivos Kanhgág. Vanessa, sua principal amiga e interlocutora, nos recebia com alegria. Iracema encontraria pessoas Kanhgág residentes de Porto Alegre que preferiram retornar aos acampamentos do que viver na capital, sob a alegação de não se adaptarem à vida na cidade. Ficamos pouco; Iracema tinha pressa, não poderíamos chegar à noite na aldeia. Nos despedimos e, retomando a viagem, fomos informados por Iracema de que iríamos dormir na casa de seu irmão, Valdir Kawag, que não sabia de nossa chegada. Afinal, Iracema estava ansiosa por retornar ao local onde enterraram seu umbigo, após longos vinte e cinco anos. Iracema tinha se reencontrado com Valdir em junho de 2014, após 13 anos de silêncio, durante uma viagem até Kandóia. Após esse primeiro e emocionante reencontro, Valdir e Iracema fortaleceram seus laços, cada um procurando ao outro quando precisava de apoio. Valdir reside num dos setores da Terra Indígena de Serrinha (TI Serrinha, Fág Kava), onde se encontrava o umbigo e o corpo do pai e da mãe de ambos. Valdir era um anteparo e local de repouso antes de chegarmos à cidade de Nonoai e, respectivamente, à TI Nonoai.

A casa de Valdir fica numa das extremidades da TI, entrecortada pelos limites políticos de dois munícipios gaúchos - sua residência fica na porção do pequeno munícipio de Engenho Velho. Valdir, ao chegar em casa, nos saúda oferecendo um chimarrão e prontamente inicia um relato sobre a situação na TI Serrinha, os efeitos na aldeia após as eleições municipais de Engenho Velho e sua posição contrária frente aos arrendamentos de terra. Essa narração o faz lembrar o trabalho de seu 
pai, juntamente com mais de sete dezenas de famílias Kanhgág, na retomada de Mangueirinha, no Paraná, um apoio solicitado pelo próprio Ângelo Kretã. Como uma conversa, Iracema notava fatos e situações que a ajudaram a adensar sua própria perspectiva sobre os acontecimentos em Mangueirinha; os antropólogos dialogavam a partir daquilo que Iracema já os tinha relatado. Os melhores colchões, cobertas e travesseiros da casa foram oferecidos aos hóspedes; exaustos tratamos de proceder a uma outra viagem: onírica. Cedo, a primeira pergunta de Kawag às visitas era: "Dormiram bem? Com que sonharam?" Mudos, às vezes monossilábicos, gaguejávamos alguma resposta. Por volta das seis horas da manhã, Kawag saía para o trabalho (é peão numa das lavouras de soja dentro da TI). Seus filhos mais velhos, na noite passada, foram à serra gaúcha nas lavouras de uva, cebola e alho trabalhar para colonos descendentes de famílias italianas que, séculos antes, se apropriaram daquele território.

No dia seguinte, nos encaminharíamos para Nonoai e, em menos de uma hora, estaríamos passando pelo portal de boas vindas da cidade, saudando os visitantes em português e em Kanhgág. Chegamos ao Posto Indígena, um dos setores da Tl e local onde Iracema passou sua infância. Procurávamos a casa de Fátima, uma sobrinha de Iracema, que nos atendeu bem, mas Iracema falou que precisaríamos encontrar outro local, pois sentia que estava sendo observada e receava por nossa segurança. As poucas fotos que tiramos fazem parte desse sentimento, desse medo, da continua aflição de Iracema ao retornar ao local onde nasceu e sofrera perseguição. Como se adivinhassem nossa presença, nos deparamos com viaturas da Brigada Militar, que estavam dentro da aldeia. Era um misto de sensações, pois estávamos ansiosos, angustiados, alegres e tristes ao mesmo tempo.

Iracema nos leva até o rio onde nasceu, o goj pixé. Chamavam o rio assim porque, antigamente, os Kanhgág se juntavam numa de suas margens para fazer o pixé, a bebida da festa. Serravam um tronco, depois o abriam ao meio e é dentro desse tronco que os antepassados faziam a bebida gostosa de mel e de fruta (ROSA, 2005). O rio era um ponto de 
encontro onde os antigos brincavam e se alegravam. Há 25 anos Iracema não via aquele rio. $O$ reencontro foi um golpe na cara, uma facada nas costas. O rio está destruído! Metade de seu tamanho, comparado a vinte e cinco anos atrás. A água estava parada, como se estivesse morto, e o fluxo do rio está cortado. Reinam aí os mosquitos, que são os únicos que se alegram com nossa chegada.

Iracema olha o rio e chora. As lágrimas caem ao contemplar seu passado atropelado pela devastação provocada pelas plantações de soja, que homogeneízam a paisagem ao nosso redor. Ela olha para nós e, com os olhos cheios de lágrimas, diz: "Está morrendo...". Agarra um pedaço de folha de um antigo remédio do mato e o exprime nas suas mãos: "o que o dinheiro faz, o que o dinheiro faz!".

Imagem 4: Ga Rã banhando Vẽnh fej no goj pixé, TI Nonoai.

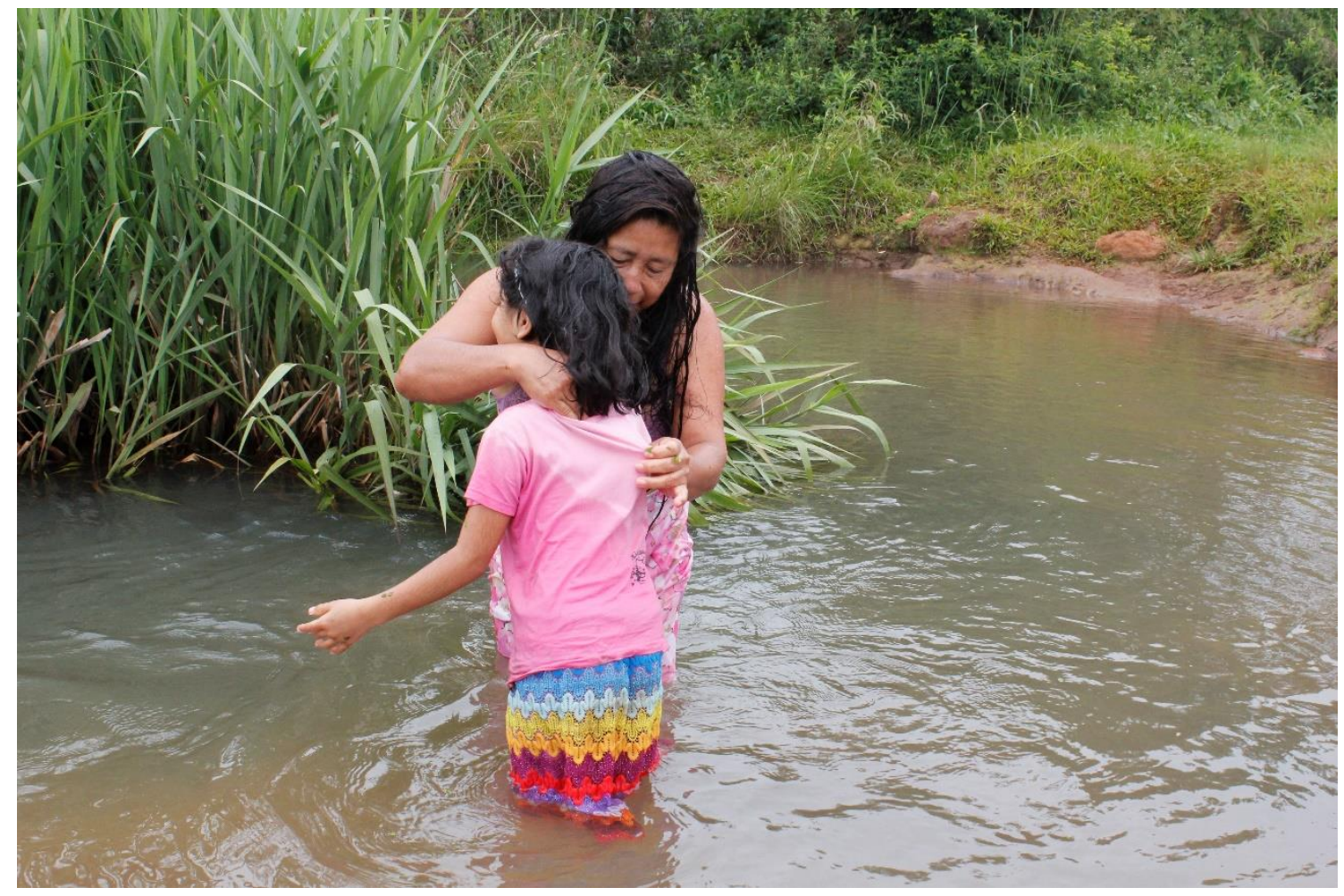

Fonte: Fotografia de Herbert Walter Hermann, 2016.

Nos custa acreditar que é desse rio que Iracema tanto nos falou. Foi aqui nesse rio que seu avó curou seus joelhos castigados por uma professora que não deixava ela falar em Kanhgág. Foi nesse rio que ela 
pediu para não casar com aquele irmão de seu pai, chefe do posto indígena de Nonoai, e foi também nesse rio que namorou pela primeira vez com Vẽnh tog, seu primeiro marido. Iracema, porém, não desiste de tomar banho e, sobretudo, de compartilhar o banho com sua neta. As duas entram na água; Iracema começa por molhar seu cabelo, e Vẽnh fej entra timidamente na água, acompanhada por sua avó. Tomam banho durante um tempo, se lavando com as ervas que estão na beira do rio.

Passamos por uma pequena ponte, desconhecida de Iracema, que opera também como espécie de barragem, não permitindo que o rio flua. Imaginamos que a água desse rio agora seja útil para as plantações de soja. Nos encaminhamos para a outra margem do rio, onde está enterrado o umbigo de Iracema. Nesse lugar, agora, brotam duas araucárias, mas Iracema explica que, quando enterraram seu umbigo, havia uma outra árvore, que fornecia frutos bem amarelos e gostosos.

Imagem 5: Onde segue enterrado o umbigo de Ga Rã.

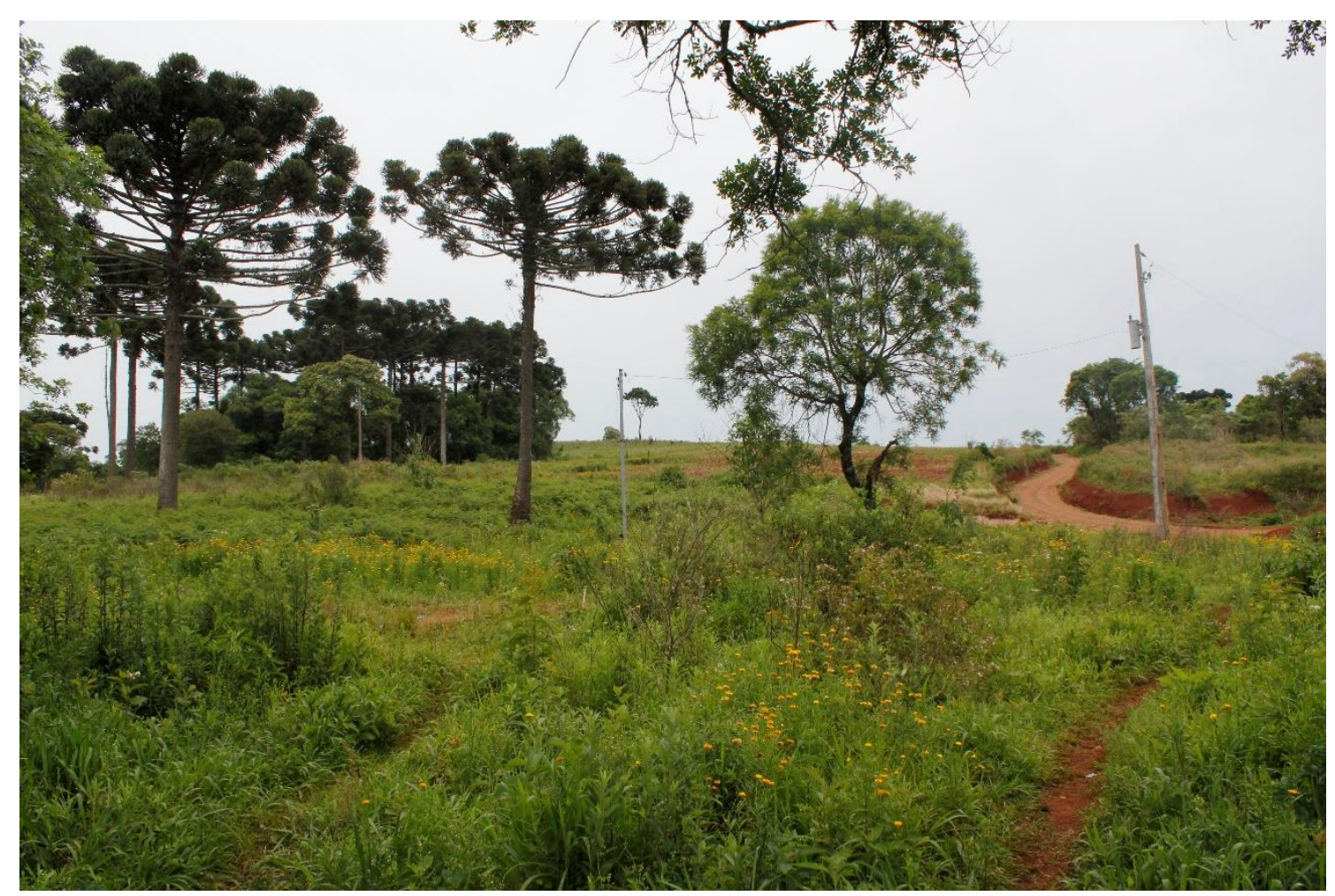

Fonte: Fotografia de Herbert Walter Hermann, 2016. 
Nos mostra até onde se estendia o rio. A extensão desaparecida é o lugar onde sua mãe lhe deu banho pela primeira vez. Também nos mostra a antiga morada dos seus pais, onde ela cresceu por um tempo, mas onde agora não tem mais nada, nem ninguém.

Imagem 6: Ga Rã apontando para local onde ficava sua casa; Vẽnh fej, à direita, aprendendo sobre a história de sua avó.

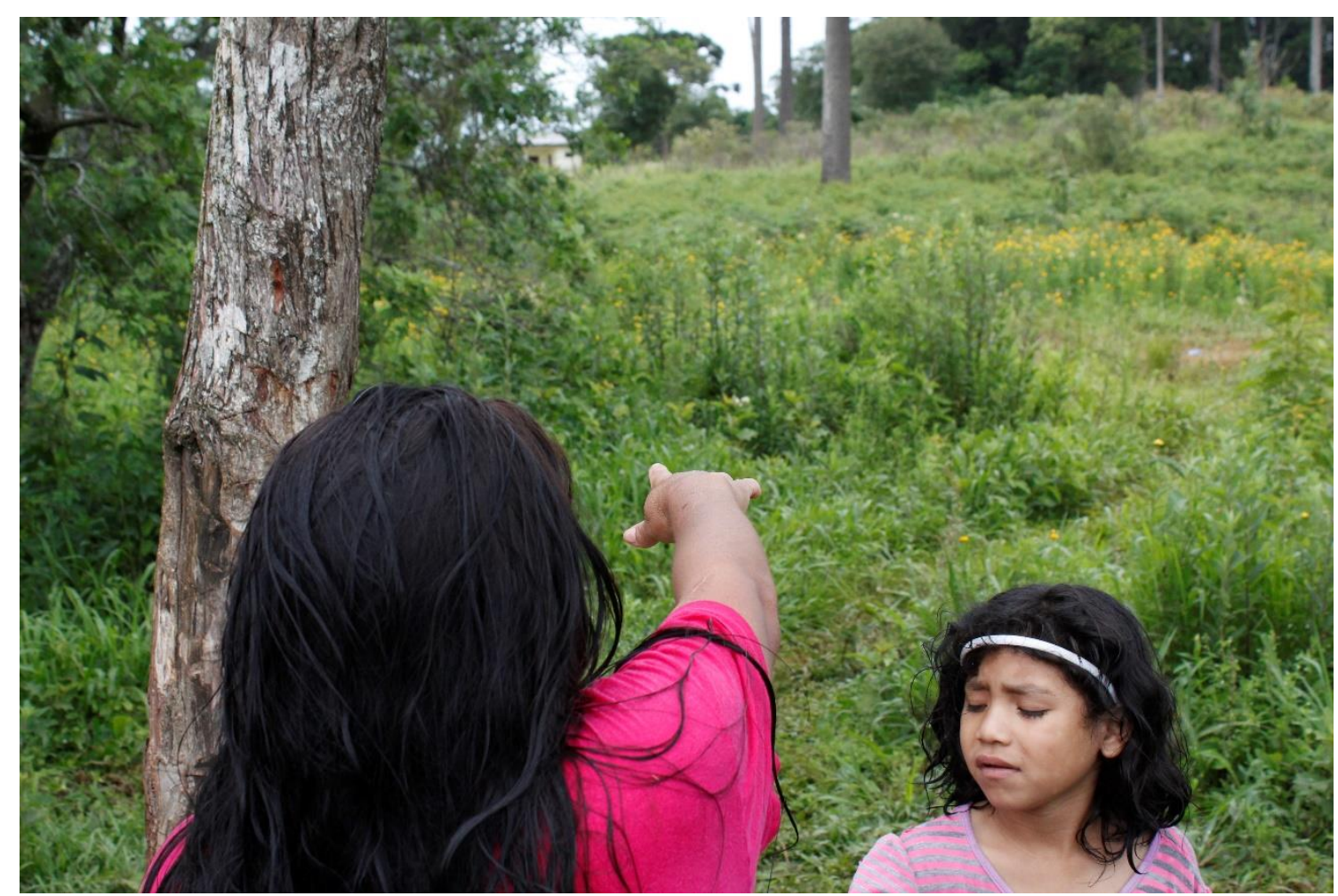

Fonte: Fotografia de Herbert Walter Hermann, 2016.

A estrada de chão pela qual entramos era uma picada de mato: não havia a estrada, não existia a ponte, não teria qualquer barragem. Muito mais água e menos soja.

Os diários de campo daquele momento, cada qual com sua carga de afeto, carregavam nossas memórias sobre a viagem. Junto com as fotografias clicadas, compunham uma espécie de retrato da situação, da viagem, dos encontros e das lutas por fazer. Mas, e Iracema, afinal, o que teria a nos relatar sobre a viagem que realizamos juntos? Como 
escreveríamos sobre essa viagem? Qual o peso que esse recorte teria nesse escrito? Que escrito seria esse? Perguntas que nos mobilizavam e fizeram com que procedêssemos em mais diálogos com Iracema, em sua casa em Porto Alegre, nas semanas seguintes à viagem em que reencontrou o local onde seu umbigo foi enterrado.

Iracema: eu nasci embaixo do Xakin Krê, que os fóg chamam de Cabotã. Duas árvores bem grandes $\mathrm{e}$ embaixo desses que minha mãe me ganhou, com sete meses e meio. Eu nasci perto de um rio bem grande. Após eu nascer eles me lavaram no mesmo rio. Quem enterrou meu umbigo foi minha avó e depois ela me enrolou com folha de bananeira. Daí, eles me levaram para casa. Mas, antes disso, meu pai teve que fazer uma tarefa que demorou, como que chama? Com a placenta. Daí como meu pai demorou, minha avó pediu para o meu pai correr em volta da minha mãe, enquanto ela sentia dor. Eu perguntei para minha mãe se ela sentia dor, ela disse que não. Daí ele corria em volta dela. Na hora que ele caiu, nasci, daí elas deram banho na minha mãe e fomos para casa, de pau a pique barreada. E lá não existe mais a árvore que eu nasci. Aquele rio que fomos pra ver, eu fiz questão de ir mostrar lá, de tomar banho lá. Eu senti que estava sujo, né, Cleme [Clementine], dava para ver o peixe, a gente pegava aquele peixe cascudo, a gente só botava a mão no buraco da pedra e na hora já pegava. Meu pai me deu banho com aquela mesma erva que eu dei banho na Vẽnh Fej. Ele me deu banho com ela quando nasci. Aquela erva é sempre sagrada para os Kanhgág. Aquela está quase extinta. Lá pra cima nem tem mais. E é importante pra mim, por isso que eu fiz questão de ir pra lá.

Clementine: E como você se sentiu na volta, Iracema?

I: Na volta eu me senti bem, que eu vivi tudo naquele dia que aconteceu. Na volta me senti bem, mas eu sei que eu tenho que passar esse conhecimento para os netos, alguém tem que passar para a frente.

C: Tu disse que reviveu tudo, o teu parto, teu nascimento?

I: Eu revi tudo, o meu parto, o meu nascimento. Revi minha avó, meu pai, meu avô, minha mãe. Revi também o irmão do meu pai, que ajudou a preparar minha mãe, minha tia. Então isso foi bom, eu voltei naquele tempo, 
de viver como criança lá. Isso foi muito bom pra mim. Fico tão longe, a gente devia voltar pra lá. Mas, eu tenho que fazer a base de como os Kanhgág nasceram e também compartilhar com os outros. Essa história dos Kanhgág que é bom. Antigamente os Kanhgág nasciam na beira do rio, no mato, no olho d'água. Ali mesmo tinha chá pra gente tomar. Tá certo em questão que muitos não acreditam mais, mas a história do Kanhgág é essa, não é só a minha.

\section{"O índio na cidade": continuidades coloniais e desafios descolonizadores. Diálogos com Kapri.}

Há quase seis décadas, nascia Iracema Nascimento, Ga Rã, na beira do rio goj pixé, em baixo do xakrin kré. A presença do rio e da árvore no nascimento de Iracema ressalta a importância, para o tecido relacional Kanhgág, de seres considerados pelos fóg como simples "recursos naturais". Para os Kanhgág (assim como vários povos indígenas), esses seres devem ser considerados como (cosmo)políticos da "natureza" (VIVEIROS DE CASTRO, 1999; STENGERS, 2005). Eles são quem permite o equilíbrio e a harmonia nos corpos e territórios Kanhgág. Duas gerações após o nascimento de Iracema, nascia, no Hospital Conceição, na cidade de Porto Alegre, sua netinha, Sofia. Mesmo na cidade, Iracema se empenhou em (re)construir laços com seres que, embora estivessem materialmente distantes, tornavam-se presentes na sua relação com os mundos dos cantos e dos sonhos. Kapri, sua filha e mãe da pequena Sofia, nos relatou seu parto:

Kapri: Eu fui primeiro no hospital Santa Casa e não tinha vaga, fui de ônibus com o Rodrigo [pai de Sofia], então fomos para o Hospital Conceição, onde conseguimos uma vaga, e a mãe já estava lá, esperando. Lá, as secretárias me perguntaram com quem eu queria entrar e chamei a mãe para entrar comigo. Até o Rodrigo disse para mim: "entra com tua mãe que ela vai te dar uns conselhos". Nós entramos no quarto e ela pediu para tirar minha roupa e ir pro banheiro, ficar debaixo do chuveiro com água quente para esquentar minhas costas. Ela fazia massagem para que a nenê saísse bem. Ela ficou conversando comigo bastante, explicando para mim como que seria o parto. 
C: E o que ela te dizia, tu lembras?

$\mathrm{K}$ : Mais ou menos, de tanta dor que eu tinha.

C: É muita dor?

K: Sinceramente, é bem forte; assim, não vou dizer que é horrível porque horrível não é, pois é o nascimento de uma criança, eu tinha que passar por aí, não tinha outra [risadas]. Mas foi bastante forte, e foi emocionante também, ela fez massagem, mas a dor era... Bah!...

C: Mas o que que tu sentiste?

K: Durante o parto se sente muito a dor nas costas, a pessoa não consegue parar. Como que os fóg chamam, "contração", deus me livre, pior que dor de dente, chorava e gritava, só ela [Iracema] me acalmava. Achei uma coisa engraçada, me deu fome durante o parto e eles [os médicos e os enfermeiros fóg] dizem que não se pode comer durante o parto, mas a mãe saiu um pouquinho e ela me trouxe banana para comer escondido e eu comi, foi tri que ela me ajudou [risadas].

\section{C: A Sofia demorou muito para nascer?}

K: Demorou acho que umas 6 horas, no fim o médico teve que furar a bolsa para nascer. Depois do chuveiro fiquei com dor, e me deram um comprimido para passar a dor. Com aquilo começaram as contrações, de novo, e era hora do parto, daí me levaram, aplicaram anestesia, e a mãe falou que não era bom, porque machuca o bebê, ele fica meio tontinho. O médico meio que disse que era o procedimento deles, da anestesia, na primeira vez, depois, na segunda gravidez, eles não botam. Eles enfiam uma espécie de fiozinho até o fim da coluna. A mãe disse para o médico não aplicar, mas é, eles fazem o que querem. Na hora do parto, ela falou pra mim, ela me desejou bom parto, fez uma oração, me benzeu, fez um canto bem bonito em Kanhgág e falou que esse momento era só meu e do meu companheiro e foi lá fora e chamou o Rodrigo dizendo para ele: "entra aí, tu tem que acompanhar ela, é tua companheira para ver esse momento". Ele veio e já nasceu a Sofia, tem as fotos... Achei massa, achei tri bom que ela estava aqui...

Além de reafirmar a hegemonia da biomedicina, permeada por uma bipolítica que permeia muitas das relações entre os fóg e os Kanhgág, o 
testemunho de Kapri ressalta a continuidade dos esforços de Iracema por ensinar, transmitir e seguir fortalecendo seus saberes estando na cidade. Ao chegar em Porto Alegre, "no meio dos fóg", ela segue lutando com seus avós, ensinando aos seus filhos e netos valores e sentires, deixando abertos caminhos possíveis para o(s) futuro(s) Kanhgág.

O reencontro de Iracema com seu umbigo nos projeta até sua infância, incentivando-nos a imaginar seu passado: pessoas, paisagens, momentos vividos. Em um movimento contrário, essas imagens do passado nos convidam a refletir sobre o nosso presente, nos colocam em uma matriz colonial em que as relações (com os fóg e com os parentes) são atravessadas por estruturas de poder. Os trabalhos de Iracema: os sonhos, as curas, as rezas, os cantos e os conhecimentos ensinados aos fóg e aos parentes são desafios descolonializadores que ela leva adiante. Kapri, sua filha, lembra da sua infância e de como sua mãe, desde muito jovem, caminhava seguindo os passos do seu avô, ensinando e cuidando dos parentes e mesmo dos fóg que pediam para ela tratamentos e curas.

Kapri: A gente ia pro mato, lá pro Morro Santana, juntar as ervas, ela moía tudo, deixava de molho e depois vinham pessoas para tomar banho, os fóg, os vizinhos vinham tomar banho, tomar chá principalmente, para ficarem bem, tínhamos chás pra fazer xarope. O pai e a mãe conhecem todos os tipos de remédios. Me lembro também das orações que ela fazia, também comigo. Eu me lembro no terreno do Jari, tu já foi lá, tu sabe que é grande, pois, já morou umas 15 famílias lá, eu me lembro que as crianças e até os adultos se machucavam no mato. Antes de ter aquele mercado [o Supermercado Guarapari], tinha um campinho onde os guris jogavam bola e ficavam brincando. Às vezes se machucavam e tinham uns que se machucavam no mato quando tiravam material para o artesanato. Eu me lembro que ela ia, ou pedia pros guris, pegar os remédios, esmagava, fervia água e fazia o remédio, depois passava neles e fazia também, como que ela chamava... botando álcool na garrafinha... o nome $[\ldots]$

C: Nós falamos tintura...

K: É, não me lembro o nome, chacoalha na garrafa, fazia fermentar, como ela fala, tu deixas isso por um tempo. Me lembro que, uma vez, me machuquei feio com minha perna, e acabou inflamando, e me lembro que ela usou 
"penicilina", aquela folha roxa e aquela folha de mamona. Passou durante dois dias e a inflamação passou, só de colocar a folha em cima, com um pouco de banha de porco, isso puxava a inflamação a folha de mamona, me lembro. Eu me lembro também que ela lavava meu cabelo com aquela folha toda espinhosa, babosa, ela descavava, amassava aquele gosmento que fica amarela e passava no meu cabelo e deixava um tempo e depois enxaguava. Me lembro que ela cuidava das pessoas na vizinhança, era bom.

Hoje, Iracema e Kapri são duas mulheres guerreiras, que seguem lutando pelo povo Kanhgág desde seus espaços na cidade de Porto Alegre e além dela. Kapri está na universidade e toma esse espaço como uma ferramenta de luta, tanto para conhecer melhor o pensamento dos fóg, quanto para dar-lhes a oportunidade de conhecer melhor a cultura e os saberes Kanhgág - porque, segundo ela, se o mundo está assim, doente, é porque os fóg são ignorantes demais, porque eles ainda não aprenderam o suficiente dos indígenas.

Iracema também vê sua atuação na universidade como uma ferramenta interessante para interpelar os fóg sobre a hegemonia dos seus saberes e da sua ciência. Ela sabe escrever "só seu nome", porém, leva consigo na pele, no coração, nos pés, nos cabelos longos e pretos e nos olhos profundos, milhares de anos de experiência, também colonial, de resistência Kanhgág e propostas descolonizadoras. Embora os contextos atuais sejam cada vez mais difíceis de enfrentar, Iracema encontra na cidade um espaço - um território Kanhgág - de luta e de criação de afinidades entre parentes e com alguns fóg. Um lugar onde os filhos e os netos vão crescer e buscar, por sua vez, enfrentar uma colonialidade atravessada por processos de recolonização, cada vez mais complexos (KRENAK, 2015).

\section{Referências bibliográficas}

ABU-LUGHOD, Lila. Locating Ethnography. Ethnography, v. 1, n. 1, 2000. 
AQUINO, Alexandre de Magno. Ën ga uyg ën tóg ("nós conquistamos nossa terra"): os Kanhgág no litoral do Rio Grande do Sul. 2008. 213 f. Dissertação (Mestrado em Antropologia Social) - Brasília: Universidade de Brasília, [2008].

CATAFESTO DE SOUZA, José Otávio. “Aos Fantasmas das Brenhas": Etnografia, invisibilidade e etnicidade de alteridades originárias no sul do Brasil. 1998. 492 f. Tese (Doutorado em Antropologia Social) - Porto Alegre, Universidade Federal do Rio Grande do Sul, [1998].

CLASTRES, Pierre. Arqueologia da Violência: pesquisas de antropologia política. São Paulo: CosacNaify, 2014.

DELEUZE, Gilles. Postscript on Control Societies. Negotiations. New York: Columbia University Press, 1995.

ELTZ, Diego Duarte. Corporalidades Kanhgág: as relações de Pessoa e Corpo no Tempo e Espaço Kanhgág. 2011. 148 f. Dissertação (Mestrado em Antropologia Social). Porto Alegre: Universidade Federal do Rio Grande do Sul, 2011.

FABIAN, Johannes. Time and the Other: how Anthropology Makes Its Object. New York: Columbia University Press, 1983.

FAVRET-SAADA, Jeanne. Être Affecté. Gradhiva - Revue d'Histoire et d'Archives de l'Anthropologie, v. 8, p. 3-9, 1990.

FOUCAUlT, Michel. Aula de 17 de Março de 1976. In: Defesa da Sociedade. Curso no Collège de France. São Paulo: Martins Fontes, 2002, p. 285-315.

FOUCAULT, Michel. O Nascimento da Biopolítica. São Paulo: Martins Fontes, 2008.

FREITAS, Ana Elisa de Castro. Mrür Jykre: a cultura do cipó - territorialidades Kanhgág na bacia do Guaíba. 2005. 464 f. Tese (Doutorado em Antropologia Social) Porto Alegre, Universidade Federal do Rio Grande do Sul, [2005].

GRAVATO, Isabel Cristina Ferreira. Sustentabilidade do extrativismo Kanhgág de lianas em Porto Alegre/RS. 2012. Tese (Doutorado em Biologia) - São Leopoldo, Universidade do Vale do Rio Sinos, [2012].

HERMANN, Herbert Walter. No coração da cidade: cosmopolítica, dinheiro e afeto na luta Kanhgág pelo espaço em Porto Alegre-RS. 2016. Dissertação (Mestrado em Antropologia Social) Porto Alegre: Universidade Federal do Rio Grande do Sul, 2016.

JAENISCH, Damiana B. A arte Kanhgág da produção de objetos, corpos e pessoas: Imagens de relações nos territórios das Bacias do Lago Guaíba e Rio dos Sinos. 2010. Dissertação (Mestrado em Antropologia Social) - Porto Alegre, Universidade Federal do Rio Grande do Sul, [2010]. 
KOPENAWA, Davi; ALBERT, Bruce. A queda do do céu: Palavras de um xamã yanomami. São Paulo: Companhia das Letras, 2015.

KRENAK, Ailton. Paisagens, territórios e pressão colonial. Espaço Ameríndio, Porto Alegre, v. 9, n. 3, p. 327-343, 2015.

MARÉCHAL, Clémentine. "Eu luto desde que me conheço como gente" Territorialidade e cosmopolítica Kanhgág enfrentando o poder colonial no sul do Brasil. 2015. 213 f. Dissertação (Mestrado em Antropologia Social) - Porto Alegre, Universidade Federal do Rio Grande do Sul, [2015].

MIGNOLO, Walter. Desobediencia epistêmica: retórica de la modernidade, lógica de la colonialidad, y gramática de la descolonialidad. Buenos Aires: Ediciones del Signo, 2010.

POZZOBON, Jorge. O lumpen-indigenismo do estado brasileiro. Journal de La Société Des Américanistes, v. 85, n. 1, p. 281-306, 1999.

QUIJANO, Anibal. Colonialidad del Poder, Eurocentrismo y América Latina. In: LANDER, E. (Org.). La Colonialidad del Saber: Eurocentrismo y ciencias sociales. Perspectivas latinoamericanas. Buenos Aires: CLACSO, 2000. p. 201-246.

RABINOW, Paul; ROSE, Nikolas. O conceito de biopoder hoje. Revista de Ciências Sociais, n. 24, p. 27-57, 2006.

ROSA, Patrícia Carvalho. Gênero, espaços e práticas sociais: reflexões sobre a noção de pessoa e construção de corpos Kanhgág na sociedade contemporânea. 2008. Monografia (Bacharelado em Ciências Sociais) Porto Alegre: Universidade Federal do Rio Grande do Sul, [2008].

ROSA, Rogerio Reus Gonçalves da. Os kujá são diferentes: um estudo etnológico do complexo xamânico dos Kanhgág da terra indígena Votouro. 2005. 415 f. Tese (Doutorado em Antropologia Social) - Porto Alegre, Universidade Federal do Rio Grande do Sul, [2005].

SAEZ, Oscar Calavia. Autobiografia e sujeito histórico indígena. Novos Estudos, n. 76, p. 179-195, 2006.

SALDANHA, J. R. "Eu não sou pedra para sempre": Cosmopolítica e Espaço Kanhgág no Sul do Brasil Meridional. 2009. Dissertação (Mestrado em Antropologia Social) - Porto Alegre, Universidade Federal do Rio Grande do Sul, [2009].

Selvagens, barbárie e colonos: coletivos indígenas kaingang e o choque com a civilização no Sul do Brasil Meridional contemporâneo. 2015. 517 f. Tese (Doutorado em Antropologia Social) - PPGAS/UFRGS, Porto Alegre, [2015].

SCHWEIG, Ana Letícia Meira. Territorialidade e relações sociocosmológicas Kanhgág no Morro Santana, Porto Alegre-RS. 2014. Monografia (Bacharelado em Ciências Sociais) - Porto Alegre, Universidade Federal do Rio Grande do Sul, [2014]. 
SIMONIAN, Lígia T. L. Política/ação anti-indígena de Leonel de Moura Brizola. In: BOEIRA, Nelson; GOLIN, Tau (Org.). História Geral do Rio Grande do Sul: Povos Indígenas. Passo Fundo: Méritos Editora, 2009. v.5. p. 469-496.

STENGERS, Isabelle. La proposition cosmopolitique. In: L'émergence des cosmopolitiques. Paris: La Découverte, 2007. p. 45-68.

STENGERS, Isabelle. The cosmopolitical proposal. In: LATOUR Bruno; WEIBEL Peter (Org.). Making Things Public. MIT press, 2005. p. 994-1003.

URBAN, Greg. A história da cultura brasileira segundo as línguas nativas. In: CARNEIRO DA CUNHA, M. (Org.). História dos índios do Brasil. São Paulo: Ed. Schwarcz, 1992.

VIVEIROS DE CASTRO, Eduardo. Etnologia Brasileira. In: MICELLI, Sergio (Org.). O Que Ler na Ciência Social Brasileira (1970-1995). Brasília: Sumaré/Anpocs, 1999. p. 109-224. (v. 1 - Antropologia).

Recebido em: 01/11/2017 * Aprovado em: 04/12/2017 * Publicado em: 31/12/2017 